\title{
Analisis Kesulitan Mahasiswa dalam Menyelesaikan Soal pada Materi Pertidaksamaan dan Fungsi Limit
}

\author{
Deby Erdriani ${ }^{1, a)}$, Dewi Devita ${ }^{2, \text { b) }}$ \\ ${ }^{1}$ Universitas Putra Indonesia “YPTK” Padang \\ a) de2bye@upiyptk.ac.id b) dewidevita@upiyptk.ac.id
}

\begin{abstract}
The research is aimed to analyze students' difficulties in studying calculus on inequality and limit function in Calculus subject. The research is qualitatively analyzed using descriptive data which taken in academic year of 2018/2019 in University of Putra Indonesia YPTK, Padang. The subject of the research is 53 students majoring in Computer System. The samples are 6 students grouped into 2 high-grade students, 2 middle-grade students and 2 low-grade students. Each class taken has already represented the average scores. The research is done in February until April 2019. The data are collected by documentation and interview. The result of the research shows some factors which cause mistakes the students did in Calculus subject, namely 1) student's inability to perform mixed fraction, 2) student's inability to use theorems in case of inequality in absolute values. 3) student's inability to seek factorization in many rates, and 4) student's inability to do limit function operation in polynomial fraction.
\end{abstract}

Keywords: learning difficulties, calculus, inequalities, limit of function

\begin{abstract}
Abstrak. Penelitian ini bertujuan untuk menganalisa kesulitan mahasiswa dalam belajar kalkulus pada materi pertidaksamaan dan fungsi limit, materi pertidaksamaan dan fungsi limit merupakan materi awal dan dasar pada matakuliah kalkulus. Penelitian ini bersifat Teknik analisis data yang digunakan dalam penelitian ini adalah analisis data deskriptif kualitatif, Penelitian dilaksanakan di Universitas Putra Indonesia Padang Tahun Ajaran 2018/2019, subjek penelitian satu kelas mahasiswa jurusan Sistem Komputer berjumlah 53 orang. Sampel yang diambil 6 mahasiswa, yang dikelompokkan menjadi 2 orang dari kelas tinggi, 2 orang dari kelas sedang dan 2 orang dari kelas rendah, tiap kelas yang diambil sudah mewakili dari rata-rata kesalahaan yang dilakukan oleh mahasiswa. Waktu penelitian dari bulan Febuari sampai April. Teknik pengumpulan data dalam penelitian ini adalah dokumentasi dan wawancara. Hasil penelitian yang menyebabkan mahasiswa kurang bisa mengikuti mata kuliah kalkulus terutamanya pada materi pertidaksamaan dan fungsi limit yaitu: 1) kekurang mampuan mahasiswa dalam melakukan operasi pecahan campuran, 2) kekurang mampuan mahasiswa dalam menggunakan teorema dalam kasus pertidaksamaan dalam nilai mutlak 3) kekurangmampuan mahasiswa dalam mencari faktorisasi dalam suku banyak, 4) kekurangmampuan mahasiswa dalam melakukan operasi fungsi limit dalam polynomial pecahaan.
\end{abstract}

Kata kunci: kesulitan belajar; kalkulus, pertidaksamaan, limit fungsi 


\section{PENDAHULUAN}

Matematika merupakan salah satu mata pelajaran yang diberikan sejak tingkat pendidikan dasar sampai pendidikan menengah. Salah satu tujuan pembelajaran matematika adalah memiliki sikap menghargai matematika sebab memiliki berbagai kegunaan dalam kehidupan khususnya didunia pendidikan. Oleh sebab itu siswa seharusnya memiliki rasa ingin tahu, perhatian dan minat dalam mempelajari matematika (Nasution, 2018).

Kalkulus adalah cabang ilmu matematika yang mencakup limit, turunan, integral dan deret takhingga. Kalkulus merupakan ilmu dasar yang perlu dikuasai secara lebih luas dan mendalam oleh para mahasiswa, calon guru, atau calon ilmuwan. (Apriandi, 2016). Menurut Leithold (1988) bahwa dalam mempelajari kalkulus harus memiliki pengetahuan tentang konsep matematika tertentu yaitu trigonometri, aljabar dan geometri sekolah menengah umum.

Hasil belajar mahasiswa merupakan hasil kegiatan dari belajar matematika dalam bentuk pengetahuan sebagai akibat dari perlakuan atau pembelajaran yang dilakukan mahasiswa. Atau dengan kata lain, hasil belajar mahasiswa merupakan apa yang diperoleh dari proses belajar (Hamzah B. Uno, 2007). Oleh karena itu, faktor-faktor yang mempengaruhi prestasi belajar mahasiswa tidak terlepas dari faktor-faktor yang mempengaruhi belajar itu sendiri.

Hasil belajar adalah tolak ukur untuk mengetahui keberhasilan mahasiswa dalam menguasai pelajaran setelah mengikuti proses pembelajaran. Sesuai pernyataan Hamalik (1983) menyatakan bahwa: Hasil belajar adalah tingkah laku yang timbul misalnya dari yang tidak tahu, timbulnya pengertian baru, perubahan setiap kebiasaan, keterampilan, kesanggupan, menghargai perkembangan sifat-sifat sosial, emosional dan pertumbuhan jasmani. Dari hasil belajar tersebut dapat diketahui kesulitan yang dialami oleh mahasiswa selama proses pembelajaran.

Menurut Lithner (2011), karakteristik kesulitan belajar meliputi kesulitan pemahaman konten dan kesulitan dalam proses belajar matematika. Aktivitas belajar bagi setiap individu mahasiswa tidak selamanya dapat berlangsung secara wajar. Terkadang mahasiswa cepat menangkap apa yang dijelaskan dosen terkadang juga terasa sulit, terkadang mudah memahami apa yang dipelajari terkadang juga sulit. Dalam hal semangat terkadang semangat tinggi, tetapi terkadang juga sulit untuk konsentrasi untuk belajar.

Menurut Mutakin (2013), ada dua faktor yang menyebabkan mahasiswa mengalami kesulitan dalam mengikuti mata kuliah kalkulus 1), yaitu: minat belajar dan kemampuan dasar kalkulus yang rendah. Dari dua faktor tersebut, kemampuan dasar kalkulus yang paling dominan yang menyebabkan hasil belajar kalkulus mahasiswa rendah, 2) hasil analisis faktor menyatakan bahwa diantara indikator-indikator yang menyebakan mahasiswa kesulitan dalam mengikuti mata kuliah kalkulus adalah: (1) Anggapan mahasiswa bahwa Kalkulus tidak ada kaitan dengan Prodi Teknik Informatika, (2) kurang mampu dalam operasi pengurangan fungsi, (3) kurang mampu dalam operasi suku sejenis pecahan, 4) kurang menyukai pelajaran kalkulus, (5) kurang mampu dalam operasi suku sejenis biasa, (6) kurang mampu dalam operasi pecahan campuran, (7) kurang mampu dalam operasi penjumlahan fungsi.

Matakuliah Kalkulus diberikan pada semester kedua di prodi Sistem Komputer. Adapun bobot mata kuliah ini adalah 3 SKS dengan status wajib. Berdasarkan pengalaman selama mengajar terjadinya kesalahaan-kesalahaan dalam penyelesaikan soal pada materi 
pertidaksamaan dan fungsi limit disebabkan oleh keterbatasan kemampuan dasar mahasiswa dalam menguasai dasar-dasar dalam operasi matematika, diantaranya operasi bilangan real, pemaktoran dan konsep dari fungsi limit itu sendiri. Berdasarkan latar belakang diatas, pada kesempatan ini penulis tertarik untuk meneliti tentang "Analisi Kesulitan Mahasiswa Dalam Menyelesaikan Soal Pada Materi Pertidaksamaan Dan Fungsi Limit”.

\section{METODE}

Jenis penelitian ini merupakan penelitian kualitatif yang mendeskripsikan kesulitan mahasiswa dalam menyelesaikan soal kalkulus berupa pertidaksamaan dan fungsi limit. Teknik pengumpulan data dalam penelitian ini adalah dokumentasi dan wawancara. Dokumentasi dilakukan dengan menganalisis kesalahan-kesalahan yang dilakukan mahasiswa dalam mengerjakan soal UTS. Wawancara dilaksanakan untuk mengambil data kesulitan yang dilakukan mahasiswa ketika mengerjakan soal UTS. Wawancara dilakukan setelah peneliti mengoreksi hasil pekerjaan UTS mahasiswa, dan peneliti mengklarifikasi ke beberapa mahasiswa yang mengalami kesalahan dalam mengerjakan soal UTS, untuk memperdalam informasi tentang kesulitan apa saja yang dialami mahasiswa saat mengerjakan soal UTS.

Penelitian dilaksanakan di Universitas Putra Indonesia Padang, subjek penelitian satu kelas mahasiswa jurusan Sistem Komputer berjumlah 53 orang. Waktu penelitian dari bulan Febuari sampai April. Sampel diambil dengan teknik purposive sampling, dimana sampel diambil berdasarkan tujuan penelitian yaitu menganalisa kesalahan-kesalahan mahasiswa dalam menyelesaikan soalsoal Kalkulus. Dari subjek penelitian ini akan di analisis jawaban mahasiswa dengan kriteria sebagai berikut 1) jawaban mahasiswa mewakili kesalahan yang dilakukan oleh mahasiswa 2) jawaban nya relative relevan dengan soal tes 3) mempunyai komunikasi yang baik (Dewimarni, 2017).

\section{HASIL DAN PEMBAHASAN}

Berikut ini merupakan soal tes Ujian Tengah Semester (UTS) dengan capaian pembelajaran yang digunakan untuk mendiagnosis kesulitan mahasiswa dalam penyelesaian soal pada materi pertidaksamaan dan fungsi Limit".

1. Carilah himpunan penyelesaian dari pertidaksamaan berikut

2. Carilah himpunan penyelesaian dari pertidaksamaan berikut

$$
2|2 x-3|<|x+10|
$$

3. Carilah penyelesaian dari

$$
\lim _{x \rightarrow 2} \frac{1}{2-x}-\frac{12}{8-x^{3}}
$$

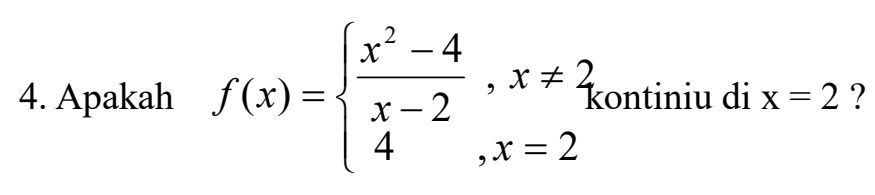


Berdasarkan hasil nilai UTS Kalkulus soal pada materi pertidaksamaan dan fungsi limit, dikelompok beberapa kelas, Mahasiswa pada kelas tersebut dikelompokkan dengan kategori yang memiliki nilai UTS tinggi, sedang, dan rendah. Dari masing-masing kategori tersebut, diambil 2 orang mahasiswa yang memiliki kesalahan paling kompleks. Setelah mahasiswa dikelompokkan berdasarkan kesalahan dan kesulitan dalam menyelesaikan soal, maka dipilih subyek penelitian untuk dianalisis lebih lanjut kesulitannya. Ada Subyek penelitian yang diambil dengan jenis kesulitan yang berbeda atau mewakili kesulitan-kesulitan yang dialami mahasiswa lain. Berikut adalah hasil analisis tes masing-masing subyek penelitian.

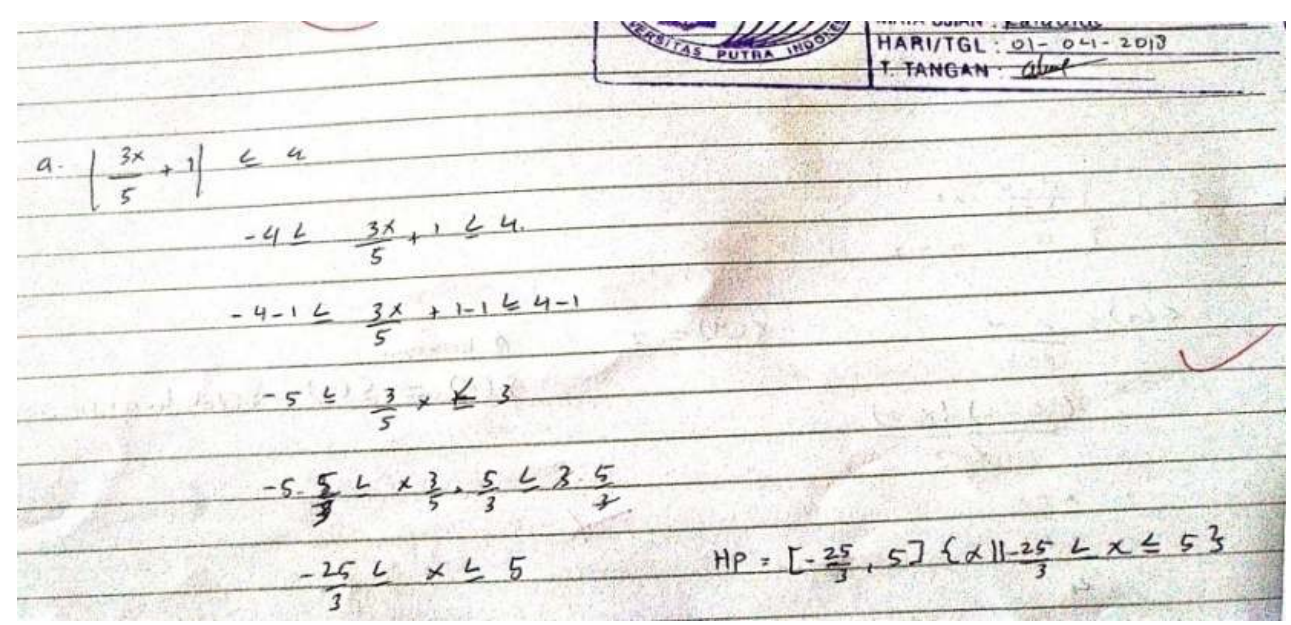

Gambar 1 Jawaban Soal Nomor 1 Kelas Tinggi

Gambar 1 pada kelas tinggi ditunjukkan cara penulisan dan pengoperasikannya sudah benar, yang perlu koreksi disini tanda biimplikasi (panah dua arah) untuk menandakan adanya hubungan jika dan hanya jika. Dikelas ini rata-rata mahasiswanya menjawab benar dalam soal nomor satu.

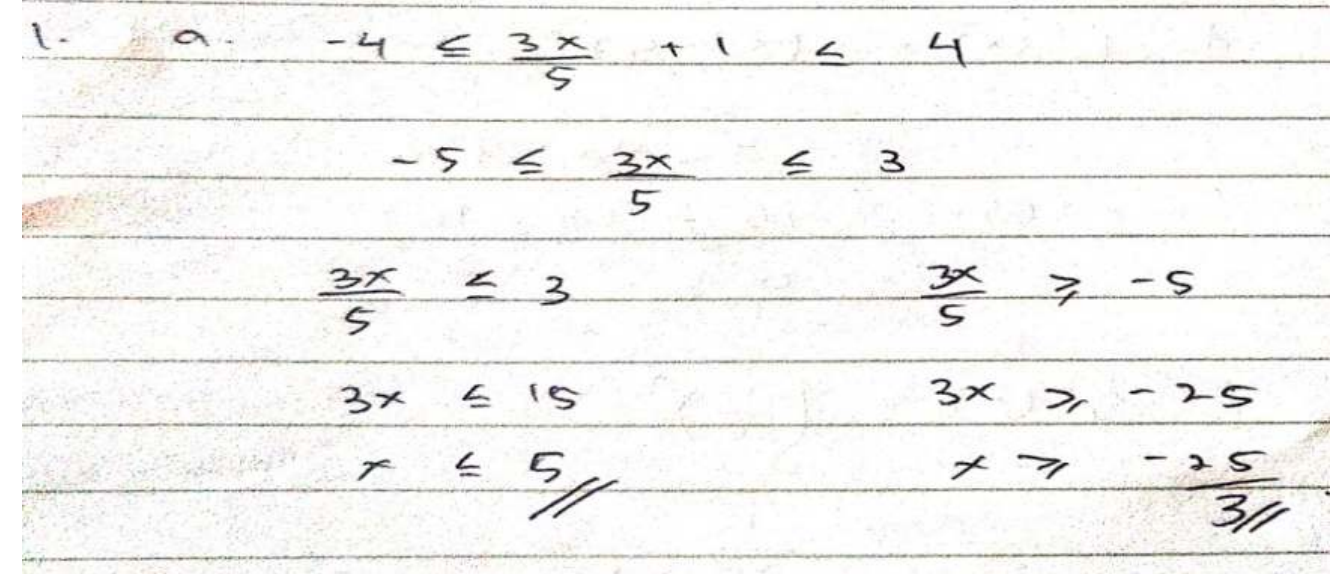

Gambar 2 Jawaban Soal Nomor 1 Kelas Sedang

Pada gambar 2 kelas sedang awalnya teorema yang digunakan sudah benar, yang keliru dalam proses penyelesainnya. Konsep dari pertidaksamaannya kurang paham dan kesalahan dalam perhitungan. 


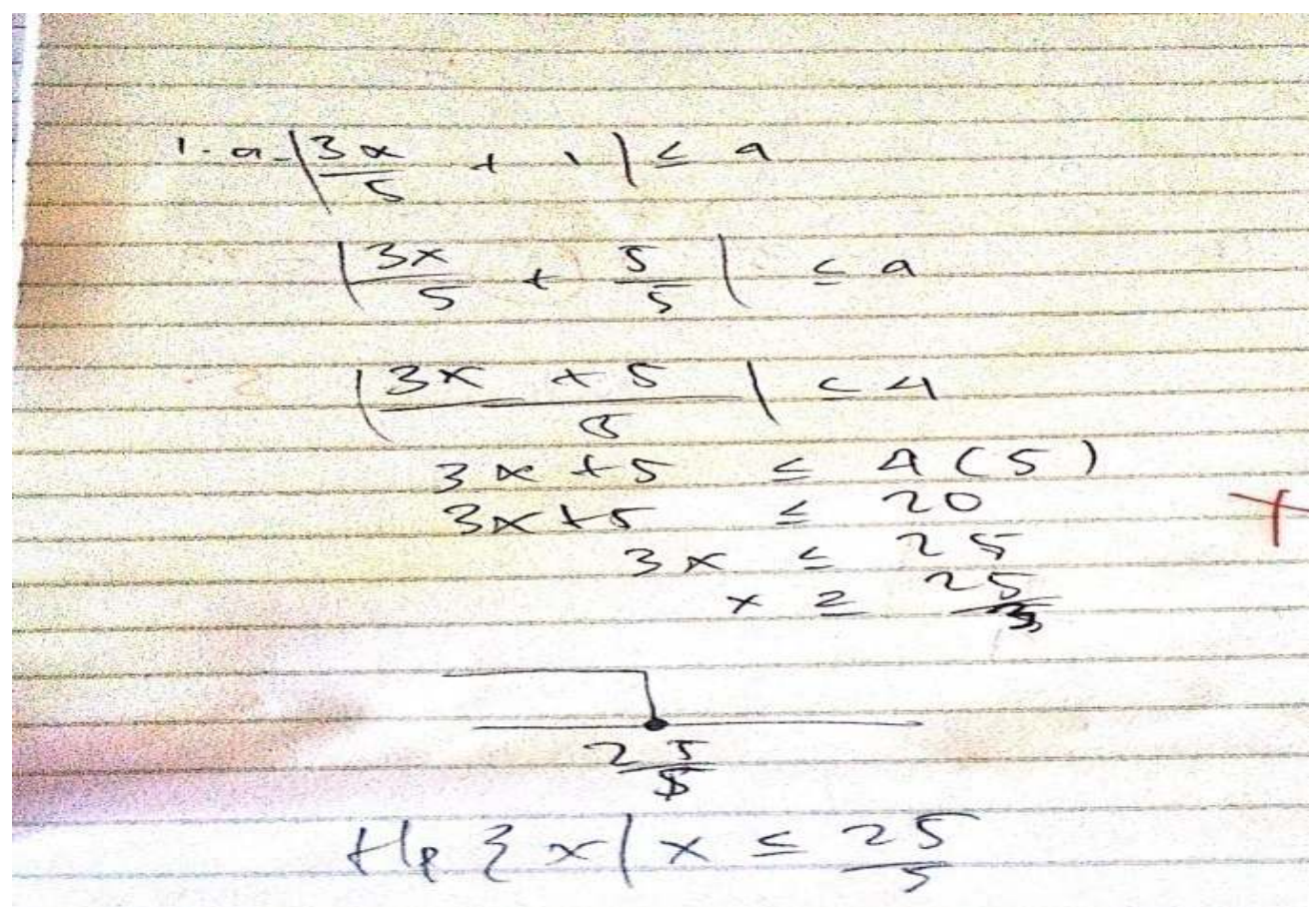

Gambar 3 Jawaban Soal Nomor 1 Kelas Rendah

Pada gambar 3 dikelas rendah berdasarkan jawaban soal diatas diperoleh bahwa mahasiswa belum memahami teorema yang tepat untuk digunakan dan cara penyelesaikan pertidaksamaan nya dengan menggunakan sifat-sifat dari operasi bilangan.

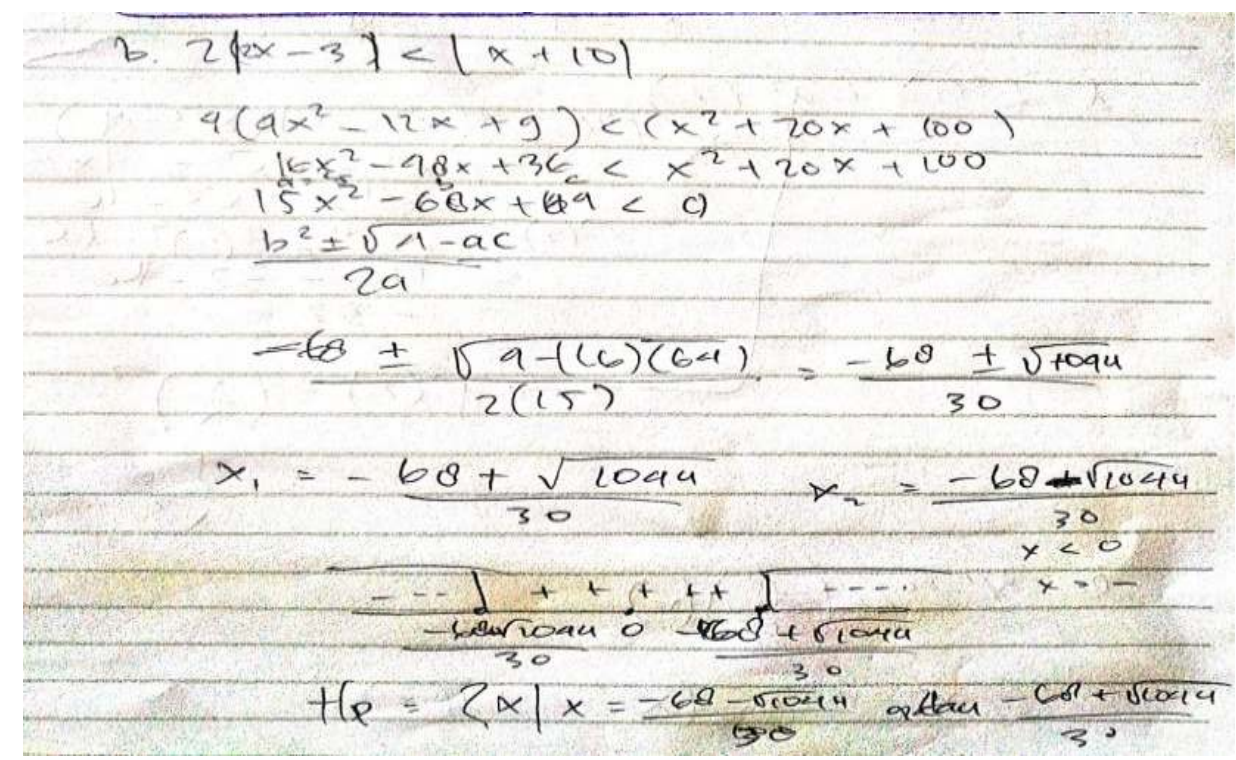

Gambar 4 Jawaban Soal Nomor 2 Kelas Tinggi

Pada gambar 4 dikelas tinggi, berdasarkan jawaban diatas teorema digunakan sudah benar, pengunaan operasi bilangannya sudah benar dan pemaktorannya menggunakan rumus abc nya salah, sehingga mengakibatkan penyelesaiannya kurang benar. 


\begin{aligned} (b) & $2|2 x-3|<|x+10| \\$ Jawab8 & $2|2 x-3|<|x+10| \\ & 2(2 x-3)^{2}<(x+10)^{2} \\ & 2\left(2 x^{2}-12 x+9\right)<x^{2}+10 x+100 \\ & 8 x^{2}-24 x+18<x^{2}+20 x+100 \\ & 8 x^{2}-x^{2}-24 x-20 x+18-100<0 \\ & 7 x^{2}-44 x-82<0<-0 \\ & (7 x+x+0 \\$\hline & \end{aligned}

Gambar 5 Jawaban Soal Nomor 2 Kelas Sedang

Pada gambar 5 pada kelas sedang, berdasarkan jawaban diatas teorema yang digunakan sudah benar,penyelesaian dan langkah-langkahnya tidak benar, sehingga diperoleh hasil yang salah dan pemaktorannya tidak bisa diselesaikan dengan baik.

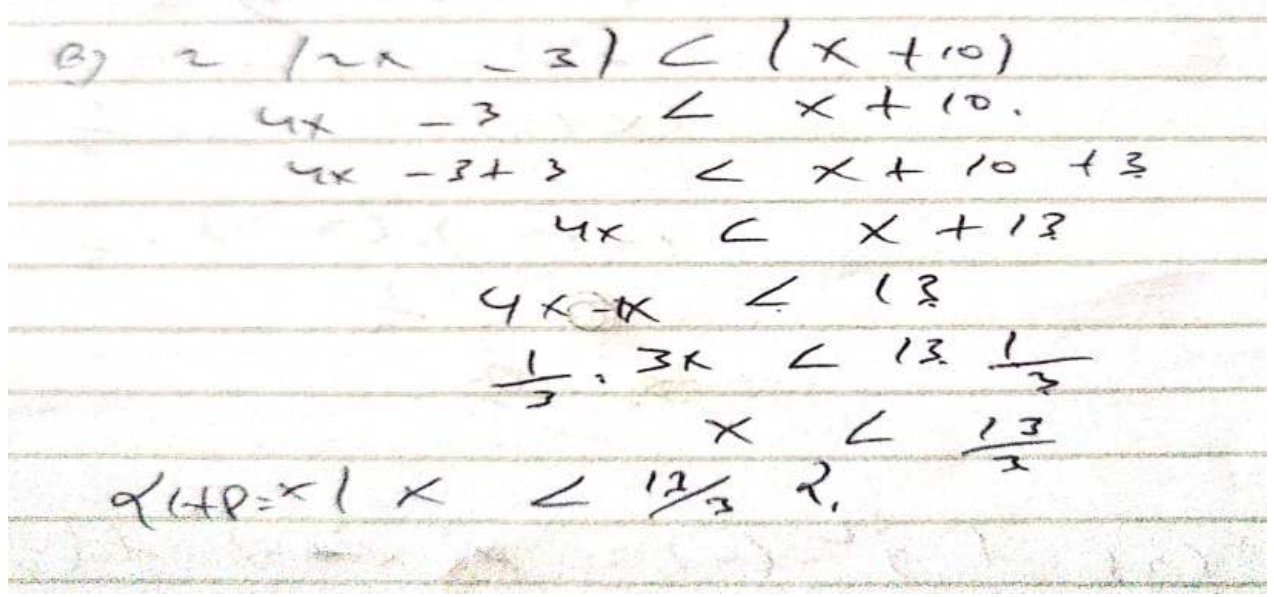

Gambar 6 Jawaban Soal Nomor 2 Kelas Rendah

Pada gambar 6 dikelas rendah berdasarkan jawaban diatas teorema yang digunakan tidak benar dan penyelesaiannya tidak benar disini terdapat kesalahaan yang komplit dalam menjawab soal. Berdasarkan pengamatan soal nomor 1 dan 2 pada kelompok kelas tinggi, sedang dan rendah, dapat kesimpulan pada materi pertidaksamaan dan nilai mutlak mengalami kesalahan dalam pengerjaan soal dikarenakan lupa atau tidak hafal sifat-sifat dari nilai mutlak, tidak menguasai konsep, lupa cara pemfaktoran polynomial dengan menggunakan rumus abc atau pembagi, dan kurang menguasai teknik berhitung. Masalah yang sama juga ditemukan pada penelitian Wahyuni (2007), yang judul penelitiannnya "Analisis Hambatan Belajar Mahasiswa Pada Mata Kuliah Kalkulus Dasar". 


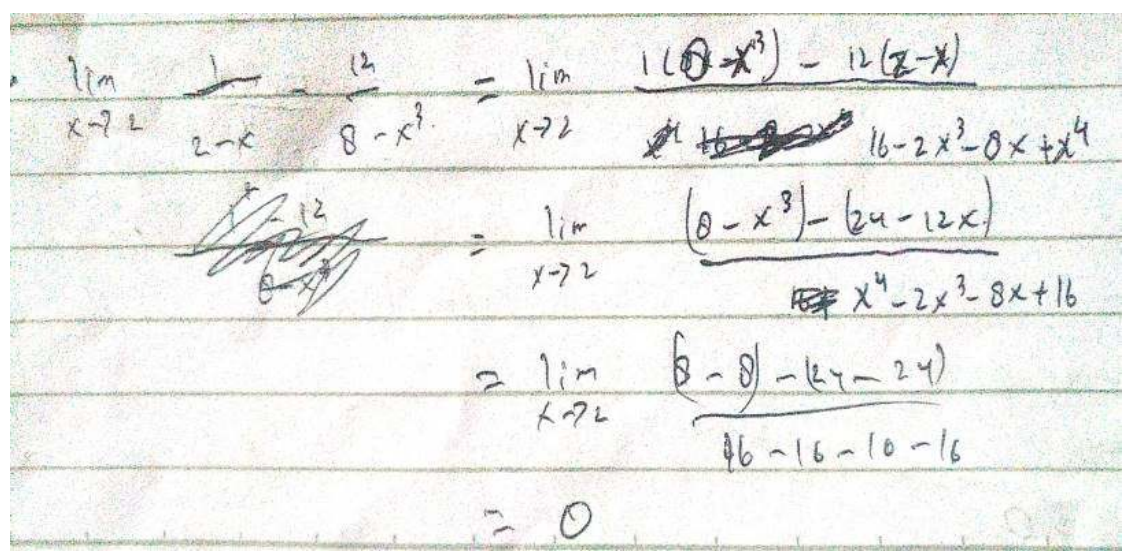

Gambar 7 Jawaban Soal Nomor 3 Kelas Tinggi

Berdasarkan gambar 7 dari hasil tes dapat diketahui bahwa Konsep tentang Teorema limit pada fungsi aljabar kurang paham dimana konsep dari $\lim _{x \rightarrow c} \frac{f(x)}{g(x)}=\frac{\lim _{x \rightarrow c} f(x)}{\lim _{x \rightarrow \infty} g(x)}$, Dengan

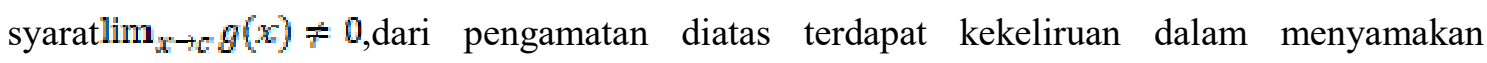
penyembut sehingga mengakibatkan hasil yang diperoleh salah.

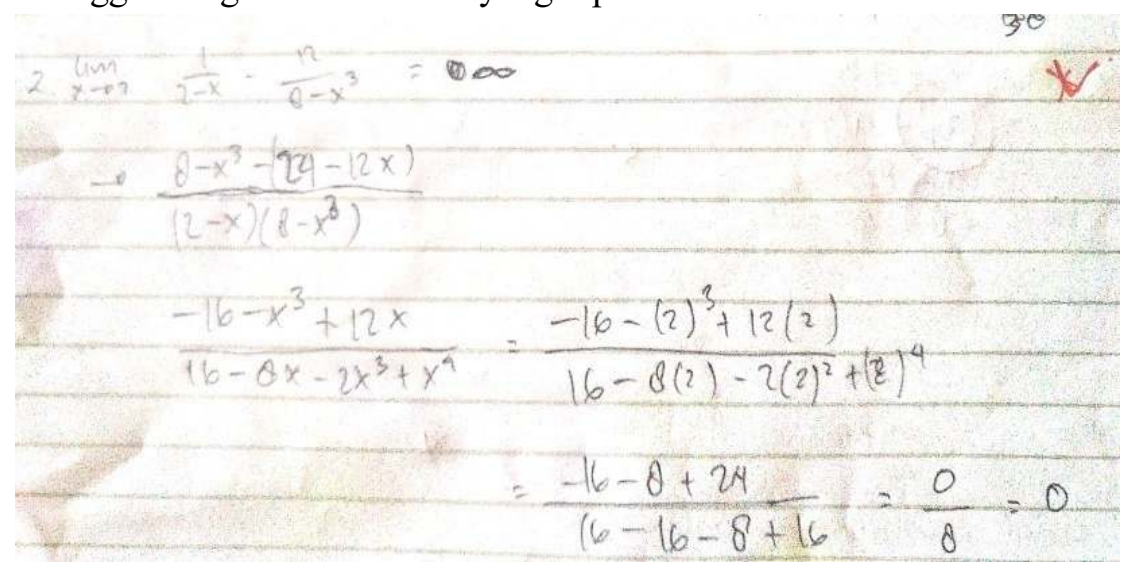

Gambar 8 Jawaban Soal Nomor 3 Kelas Sedang

Berdasarkan gambar 8 pada kelas sedang Teorema limit fungsi alajabar yang digunakan sudah benar, namun kesalahaannya pada penyelesaiannya hitungannya kurang teliti.

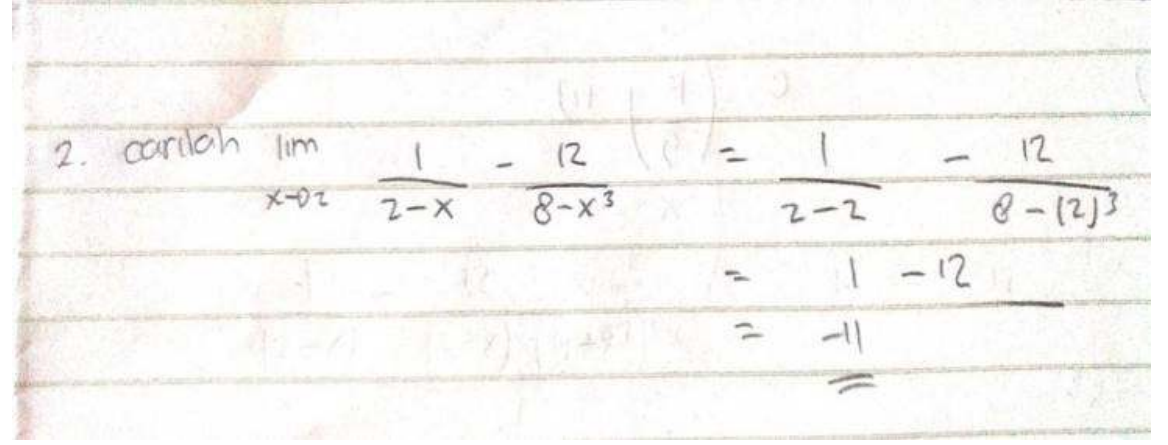

Gambar 9 Jawaban Soal Nomor 3 Kelas Rendah

Pada gambar 9 konsep tentang Teorema limit kurang paham dan Hitungannya tidak benar, pada kelas rendah ini kesalahaan diperoleh sangat komplit. Kesalahan yang dilakukan 
mahasiswa dalam menentukan nilai limit fungsi aljabar pada kelompok tinggi, sedang dan rendah diantaranya dikarenakan: a) tidak paham aturan operasi fungsi aljabar; b) tidak paham aturan limit fungsi aljabar pada fungsi polynomial; dan c) kesalahan perhitungan pada fungsi polynomial yang seharusnya disamakan penyebutnya terlebih dulu dengan menggunakan pemaktoran.

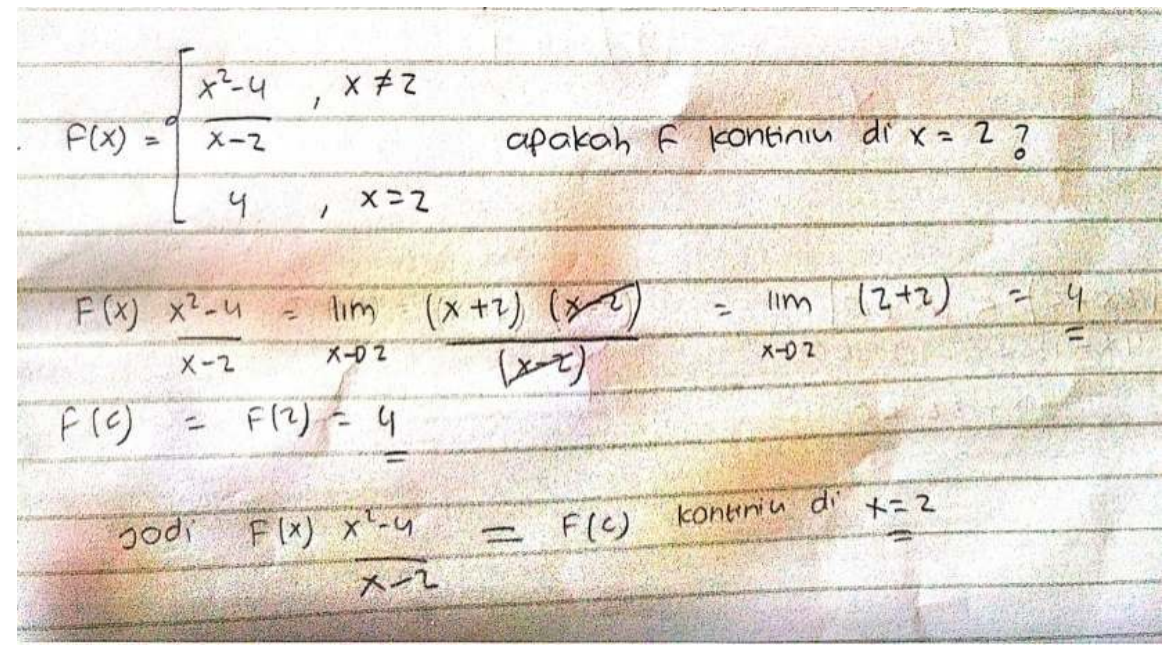

Gambar 10 Jawaban Soal Nomor 4 Kelas Tinggi

Gambar 10 menunjukkan bahwa rata-rata siswa menjawab benar, tidak banyak kesalahaan dalam menbuktikan kekontiniuan sutau fungsi. Sesuai dengan definisi kekontiniuan fungsi Mengandung arti bahwa $f$ dikatakan kontinu di $c \in A$ jika dipenuhi ketiga syarat berikut:

1) $\lim _{x \rightarrow c} f(x)$ ada; 2)nilai $f(c)$ ada dan 3) $\lim _{x \rightarrow c} f(x)=f(c)$.

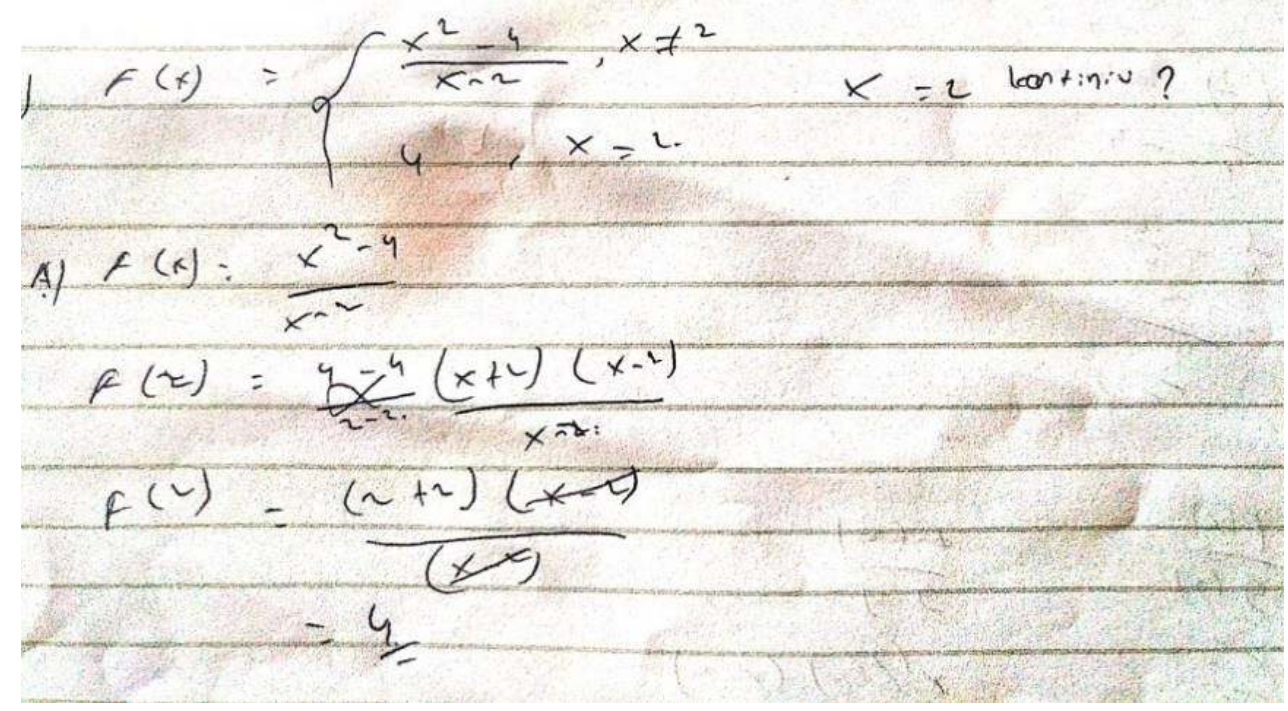

Gambar 11 Jawaban Soal Nomor 4 Kelas Sedang

Berdasarkan Gambar 11 pada kelas sedang dapat diamati bahwa definisi kekontiniua fungsi memiliki 3 syarat yang harus dipenuhi, sedangkan dikelas sedang ketiga syarat tersebut tidak terpenuhi dengan baik. 


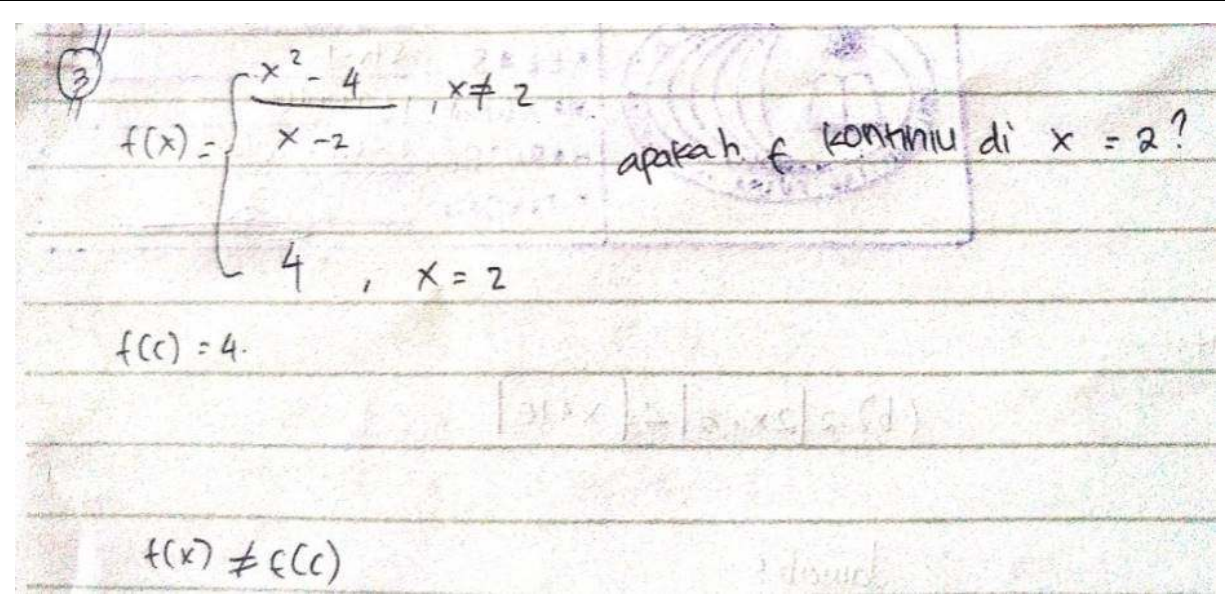

Gambar 12 Jawaban Soal Nomor 4 Kelas Rendah

Berdasarkan gambar 12 pada kelas rendah mahasiswa masih kurang paham tentang konsep dari definisi kekontiniuan fungsi. Pada materi kekontiniuan suatu fungsi, kesalahan yang dilakukan mahasiswa dalam membuktikan suatu fungsi kontiniu $\operatorname{di} c \in A$ dengan menggunakan syarat-syarat dari definisi kekontiniuan suatu fungsi, bahwa f dikatakan kontinu di c $\in$ A jika dipenuhi ketiga syarat-syarat tersebut.

Sementara itu, dari wawancara dengan beberapa mahasiswa dijelaskan bahwa ada beberapa materi dasar yang menyebabkan mahasiswa kurang bisa mengikuti mata kuliah kalkulus terutamanya pada materi pertidaksamaan dan fungsi limit yaitu:

1. Menurut mahasiswa pada materi pertidaksamaan dan nilai mutlak mengalami kesalahan pengerjaan soal dikarenakan lupa atau tidak hafal sifat-sifat nilai mutlak, tidak menguasai konsep,lupa cara menfaktorkan suku banyak untuk memperoleh nilai $\mathrm{x}$ dan kurang menguasai teknik berhitung.Pada pembelajaran kalkulus mungkin terjadi kesalahan yang mengidentifikasikan lemahnya konsep yang dimiliki mahasiswa. Jenis-jenis kesalahan yang terjadi dalam menjawab soal pada kalkulus menurut Dewanti (2013:14) yaitu (1) karena kurang cermat; (2) kesalahan karena dalam keterampilan proses; (3) kesalahan karena memahami soal; (4) kesalahan dalam transformasi; (5) kesalahan dalam menggunakan notasi.

2. Menurut mahasiswa pada materi nilai fungsi aljabar mengalami kesulitan dan tidak paham dalam aturan fungsi dan limit fungsi aljabar, serta mahasiswa kurang menguasai teknik berhitung. Sedangkan Konsep utama dari kalkulus yaitu limit, yakni materi-materi yang diajarkan dalam kalkulus adalah pelajaran tentang limit-limit,jadi penguasaan konsep limit merupakan merupakan modal utama untuk mempelajari kalkulus secara menyeluruh. Sedangkan Jenis kesalahan matematika menurut Sriati (2011:2) yaitu 1) kesalahan strategi, 2) kesalahan terjemahan, 3)kesalahan konsep, 4) kesalahan sistematika, 5) kesalahan hitung.

3. Menurut mahasiswa pada materi kekontiniua suatu fungsi mengalami kesalahaan dalam pembuktian karena lupa atau kurang teliti tentang Definisi kekontiniuan fungsi yang menyatakan "Definisi a mengandung arti bahwa $f$ dikatakan kontinu di c $\in$ A jika dipenuhi ketiga syarat berikut: 1). $\lim _{x \rightarrow c} f(x)$ ada; 2).nilaif(c)ada ; dan 3). $\lim _{x \rightarrow c} f(x)=f(c)$ 
Pentingnya penelitian ini untuk dosen khususnya untuk mengetahui deskripsi kesalahankesalahan mahasiswa dalam menyelesaikan soal kalkulus terutama pada pertidaksamaan dan limit fungsi, Memotivasi dosen untuk mencari tindakan solusi dalam mengatasi kesalahanmahasiswa dalam menyelesaikan soal pada pertidaksamaan dan limit fungsi, dan menghindari terulangnya kesalahan yang serupa oleh mahasiswa pada mata materi pertidaksamaan dan limit fungsi.

\section{KESIMPULAN}

Dari penelitian ini, dapat disimpulkan terdapat 5 jenis kesulitan mahasiswa dalam memahami pertidaksamaan dan fungsi limit yaitu : (1) mahasiswa belum memahami teorema yang tepat untuk digunakan dalam menyelesaikan pertidaksamaan dan menggunakan sifat-sifat dari operasi bilangan. Perlunya banyak latihan soal yang berbeda tandanya " $>,<, \leq$ dan $\leq$, biar bisa terlatih dalam menyelesaikan soal dengan kasus yang berbeda dan juga melatih cara berfikir dalam menyelesaikan berbagai kasus dalam pertidaksamaan; (2) mahasiswa belum memahami teorema tentang nilai mutlak yang tepat untuk digunakan dan cara pemaktoran pada suku banyak harus paham untuk mencari hasil penyelesaiannya. Sebelum mempelajari tentang pertidaksamaan dan fungsi, sebaiknya mahasiswa terlebih dahulu diberi materi tentang polynomial atau suku banyak dan cara memfaktorannya polynomial dengan berbagai metode; (3) sebagian dari mahasiswa paham tentang fungsi limit namun dilapangan masih banyak terdapat kekeliruan dalam menyelesaikan soal tentang fungsi limit; (4) pada materi fungsi kontiniu, kesalahaan mahasiswa yang tidak terlalu komplit, hanya ketelitian mahahiswa yang kurang dalam menjawab soal yang terkait dalam pembuktian fungsi kontiniu.

\section{DAFTAR RUJUKAN}

Apriandi, D \& Krisdiana. (2016) .Analisis Kesulitan Mahasiswa Dalam Memahami Materi Integral Lipat Dua Pada Koordinat Polar Mata Kuliah Kalkulus Lanjutan. Jurnal Pendidikan, 7(2).

Dewanti. (2013). Analisis Miskonsepsi Mahasiswa Program Studi Pendidikan Matematika Pada Matakuliah Kalkulus I Ditinjau Dari Gaya Belajar. Analisis Miskonsepsi Mahasiswa Program Studi Pendidikan Matematika Pada Matakuliah Kalkulus I Ditinjau Dari Gaya Belajar.

Dewimarni, S. (2017) . Analisis kesalahan mahasiswa program studi manajemen informatika universitas putra indonesia "yptk" padang dalam menyelesaikan soal- soal statistika dan probability. PHI : Jurnal Pendidikan Matematika, 1(1).

Hamzah, B.U. (2007) . Model Pembelajaran: Menetapkan Proses Belajar Mengajar yang kreatif dan efektif. Jakarta: PT Bumi Aksara.

Hamalik, O. 1983. Metode Belajar dan Kesulitan-Kesulitan Belajar. Bandung: Tarsito.

Lithner, J. 2011. University Mathematics Student's Learning Difficulties. Journal of Education Inquiry. 2 (2).

Leithold. (1988). Kalkulus dan Ilmu Ukur Analitik. Terjemahan oleh Hutahaean. Jakarta: Erlangga.

Mutakin, T. (2013) . Analisis Kesulitan Belajar Kalkulus 1 Mahasiswa Teknik Informatika. Jurnal Ilmiah Pendidikan MIPA. 3(1).

Nasution, E.Y.P., (2018). Analisis Terhadap Disposisi Berpikir Kreatif Siswa Pada Pembelajaran Matematika. Edumatika Jurnal Riset Pendidikan Matematika. 1(1)

Sriati, A. 1994. Kesulitan Belajar Matematika pada Siswa SMA. Jurnal Kependidikan Jogjakarta 
Wahyuni, A. (2007). Analisis Hambatan Belajar Mahasiswa Pada Mata Kuliah Kalkulus Dasar. JNPM (Jurnal Nasional Pendidikan Matematika). 1(1) hal.10 